\title{
In Memoriam: Robert S. Wistrich, 1945-2015
}

We are pleased to publish one of the last pieces that Robert Wistrich wrote, which is on antisemitism in France at the time of Alfred Dreyfus. It is published with an introductory essay by David Hirsh which looks at how the issues Wistrich highlights around the Dreyfus affair may be read in the contemporary context of the reemergence of antisemitism and populism into mainstream discourse.

\section{WISTRICH ON DREYFUS}

\section{David Hirsh}

Keywords: Wistrich, Dreyfus, Anti-Zionism, Antisemitism, Anti-Semitism, Arendt

When Dieudonné M'bala M'bala had his antisemitic comedy show banned by a French court in 2014, he explained this decision by alleging (inaccurately) that the judge was a great nephew of Alfred Dreyfus himself. The name still resonates with antisemitic power and it connotes the unpatriotic and scheming Jew.

Dieudonné is a most contemporary French antisemite. His Holocaust denial and the way he ridicules those who oppose antisemitism take ostensibly pro-Palestinian and anti-imperialist forms. His antisemitism inhabits the space where left and right conspiracy fantasies become indistinguishable. His "quenelle," a kind of stilted, censored, Nazi salute, is a performance jibe, articulating the notion that that the French establishment, at the behest of the Jews, silences all criticism with a false accusation of antisemitism. Every accusation of antisemitism, he teases, is in reality a mobilization of Jewish power.

Dieudonnés show, for which he had sold 6,000 tickets, was the first in a twenty-two-date tour of France. It was banned by a higher court in Nantes. French Interior Minister Manuel Valls had spoken against the tour and it was held by the court to constitute a threat to public order. And in response, Dieudonné invoked the magic word, "Dreyfus."

In her huge 1951 book Origins of Totalitarianism, Hannah Arendt articulated her rage against a world in which the Final Solution and the Gulag could exist. She was furious with everybody: the left, the right, the philosophers, the pragmatists, the ideologues, the Nazis, the Stalinists, the liberals, the imperialists, and even the Jewish leaders. Perhaps, to the degree that she herself may have fitted in to more than one of these categories, she was also furious with herself for having been unable to prevent the victories of continent-sized movements, organized on the basis of terror and on the industrialization of murder. These were not only movements which perpetrated crimes against flesh and blood human beings, but crimes which, taken together, also constituted a criminal assault on the common notion of humanity itself, and therefore on human civilization as such.

And some of Arendt's furious powerlessness, expressed in forensic and scholarly dissection of the events and the ways of thinking which led towards totalitarianism, may also be explained by the certainty that similar things would happen again and that we would be powerless, again, to stop them. In this hindsight excavation of what had gone wrong, of what led to Nazism and to Stalinism, Arendt devotes a whole chapter to the so-called "Dreyfus affair." Strange to call it an "affair." A "sequence of 
events of a specified kind or that has previously been referred to." To call it an affair is already to discuss not the thing itself but the ways in which the thing itself has been bundled up into narratives and ready-made packets of thinking, each saturated with emotional power and commitment. And then, is there not something inescapably absurd or perhaps necessarily trivial about an affair?

Robert Wistrich, a driven historian and opponent of antisemitism, wrote this piece about the Dreyfus affair in 2014 and he died prematurely and suddenly in 2015; much missed by friends, colleagues. and a wider public. Already the 2019 world in which this piece is being published would be in some ways unrecognizable to the author. In 2014 the only references to the Trump presidency were facetious, dystopian humor in Back to the Future and The Simpsons. "Euroscepticism" was still an earnest and dusty eccentricity in Britain, on the nostalgic Tory right and on the Stalinist-nationalist left. Steve Bannon, Matteo Salvini, Nigel Farage, and Jeremy Corbyn were eccentric figures, little known, working away in their fringe spaces. Their fantasies of mainstream power were taken seriously by nobody but themselves and perhaps by their own circles of cronies.

But Robert Wistrich did understand left and socialist antisemitism, he did fear it, and he did prophesy its rise. In 2012 he published his last major work on it-From Ambivalence to Betrayal: the Left, the Jews, and Israel. ${ }^{1}$ Yet perhaps he might still have been dismayed if he knew how right he had been and how quickly, not least in the UK, the country from which he made Aliya to Israel.

We read history in the present. We are thinking about the Dreyfus affair today, at a moment when many of the characteristics which Arendt identified as defining totalitarian movements are becoming more and more apparent in political life, and in the life of public discourse more generally. And Hannah Arendt saw in the Dreyfus affair a number of the elements which were later to come together in totalitarianism.
Perhaps the most striking thing about the Dreyfus affair in relation to the rise of contemporary populism is its symbolic nature. For Dreyfus, of course, what happened to him was not symbolic, it was not "an affair": it was his own catastrophe. He was a good army officer; a modernizer and a meritocrat, an honorable and courageous soldier. The fake accusation of betrayal made against him was in fact a real betrayal of him, by people who he thought were his peers, his fellow officers , and his comrades; he thought he was one of them, or that he could be one of them.

The experience is of being pushed out of social spaces in which one feels at home and of being made socially homeless before being made actually homeless; of losing one's friends before losing one's citizenship; of losing the respect of one's peers. While we still cannot quite believe that this is happening to us, while we still wonder if we ourselves are simply imagining the surging and dimming of the gaslight, this is the experience of many Jews today.

I have recently seen younger Labour activists say that if they had been told five years ago that Labour antisemitism would have been so explicit and ubiquitous as to make them feel driven out of the party they would have been shocked. But five years ago, many of us had already been through all this in the University and College Union (UCU), and we'd been writing about it for the previous eight years—as loudly and as persistently as we possibly could. The Fraser trial was in 2012. When all the evidence from UCU was presented, we were told by the judges that we had invented all the antisemitism in order to gain a sneaky advantage in the Israel/Palestine debate.

I don't blame them (the young activists, I mean; I do blame the judges in the Fraser trial). I suspect people simply can't believe the significance of antisemitism, or understand it, until they have felt it themselves. Which is why so many good people look at the evidence, accounts, and explanations with dead eyes; and make a judgement that it's overblown or not 
significant compared to other things; or think it is part of a conspiracy to silence criticism of Israel; or that it is "weaponized"; or Jews that are privileged.

I was quite shocked when I first saw it in 1985 in the student movement; and I was very shocked again when I first experienced it as an adult on campus in 2004.

And Jewish feminists were quite shocked when they were driven out of the Spare Rib collective in the late 70 s because they declined a polite invitation to disavow "Zionism."

And Jewish Czech communists were quite shocked when they were hanged in 1951, at the time of the Slansky trial.

And Alfred Dreyfus was quite shocked when he was falsely tried by his fellow officers and was sent to Devil's Island.

And Karl Marx was quite shocked when Bruno Bauer told him that Jews could only be emancipated in Germany on condition that they first emancipate themselves from their barbaric religion.

The proto-totalitarian nature of turn of the century France was clearer, more explicit, and better developed than we see across the world today; the mob was closer at hand and its violence was more immediately threatening. But then, on the other hand, there was not yet the experience of totalitarianism, drawn in stark images on the wall, to show people precisely what they should fear; or what they should ridicule others for fearing. When Zola stood up for Dreyfus, the mob literally came to his house and smashed his windows and later he was imprisoned. When academics stood up for Dreyfus, their university rooms were trashed by the mob. The police and the state could not be relied upon to defend one from crowds of antisemites. A Twitter dogpile is not the same as a mob trying to kill you. Yet still, there are clear parallels between that world and our own.

Theodor Herzl, later celebrated, and demonized, as a key founder of the Zionist movement, witnessed the publicly staged humiliation of Alfred Dreyfus. He was present at the expulsion of Dreyfus from the community to which he thought he belonged, the explicitly ceremonial stripping of his epaulettes, and the breaking of his sword. He witnessed the figurative throwing of Dreyfus by the elite to the mob; literally a baying, Jew-hating mob. For Herzl this scene was illustrative of the necessity for Jewish national self-determination and of the danger of Jews relying on the democratic republic to guarantee their safety. Dreyfus was taken to Devil's Island and his guards were instructed not even to talk to him such that he began to forget how to talk. And the Jewish man endured the explicit daily humiliation of being forced to exist on a diet of rotting pork.

Hannah Arendt ends her chapter on Dreyfus with the following observation, which may surprise some on both the left and the right who mistakenly read Arendt as an antizionist:

Thus closes the only episode in which the subterranean forces of the nineteenth century enter the full light of recorded history. The only visible result was that it gave birth to the Zionist movement-the only political answer Jews have ever found to antisemitism and the only ideology in which they have ever taken seriously a hostility that would place them in the center of world events. ${ }^{2}$

Yet if his story is not symbolic for Dreyfus himself, but concrete, it comes to appear symbolic for everybody else. Robert Wistrich quotes Maurice Barres, an "anti-Dreyfusard" in 1898: "That Dreyfus is guilty, I conclude from his race." We learn from this that Barres had no idea at all if Dreyfus was actually guilty or not and that it was of no importance to him. For him, Dreyfus's guilt was a symbolic and moral certainty, not a material question. It was an issue which separated the good people in France from those who were said to threaten their way of life. The suffering of one man on Devil's Island is not, in this way of thinking, significant when put in the balance against the survival of the nation. 
When the crime against Dreyfus was transformed into an "affair" it became a language with which to fight culture wars, a way of performing one's own identity. Dreyfus became the raw material for the sharing of meanings about what it meant to be French, what it meant to be patriotic, and what it meant to be loyal to the republic.

But the concrete events were not randomly constructed as "the Dreyfus affair." Antisemitism begins with a concept of its own creation, "the Jews," and it shapes reality to fit this fantasy. Antisemitism, created by people who feel powerless, is a fantasy about powerless people running the world. The Jewish monolith invented by the antisemites is then mapped onto the bodies of actual Jewish men, women, and children. The plausibility of antisemitism, or its implausibility, is conditioned by the ways in which the diversity of Jewish human beings is made to appear identical to the mythical "the Jews."

Mahathir Mohamad, the prime minister of Malaysia, said recently at the Cambridge Union that he "had some Jewish friends, very good friends. They are not like the other Jews, that's why they are my friends." ${ }^{3}$ Himmler himself famously commiserated with himself that '... . all the 80 million upright Germans, and each one has his decent Jew. They say: all the others are swine, but here is a first-class Jew." ${ }^{4}$

It is both true that Dreyfus was a man and that the "Dreyfus affair" was about competing narratives relating to French identity, betrayal, and the republic. The meat was both pork and it was also rotting. The issue was the suffering of one man but the issue was also the meaning of democracy.

The Dreyfus affair was not randomly constructed, it was constructed by antisemitism. Antisemitism portrayed the particular Jewish man only as a tentacle of "the Jews" and not at all as a man with interests of his own, agency, or reason. And it thereby framed the discussion. Alfred Dreyfus was hated by his fellow officers as a modernizer, as a supporter of a new meritocratic ethos in the army, and then as "not one of us," and then as a Jew.
Many scholars today do not hyphenate the word "antisemitism." They want to indicate that the "semitism" to which antisemitism is opposed is not something found in the world but that it is invented by the antisemites themselves. Some scholars are now dropping the hyphen in antizionism for the same reason. The "Zionism" in opposition to which antizionism defines itself is similarly self-constructed; it is a "Zionism" which means racism, imperialism, apartheid, and Nazism. Antisemitism has always put the Jews at the center of all that is bad in the world, and it made the Jews symbolic of what was bad in the world. Antizionism puts Israel at the center of all that is bad in the world - the block to peace across the whole region, the demonic developer and inventor of technologies of surveillance and securitization, and symbolic of the global domination of "whiteness."

Jews are cast out of "whiteness" by white supremacists, and they are more and more cast out of the resistance to white supremacists by being themselves designated as "white," and then, in a vile inversion, as "white supremacists"; a double bind which becomes farcical when it is remembered that half of the Jews of Israel could not pass as "white" in any sense that any racist would recognize. But the Israel which the antizionists hate, the mythical Israel, the Israel which constitutes the raw material for our own performances of identity, bears only the most superficial resemblance to the Israel which exists in all its material complexity and human contradiction.

Dreyfus was cast as the Jew, from the outside and independently of his own self-consciousness, an indivisible atom or cell of "the Jews." In our day, antizionism casts Jews in general as representatives of Zionism, even if it allows in principle for exceptional good Jews to be absolved. The diverse and plural identities of Palestinian men and women are appropriated, unified, and redrawn as universal symbols of the oppressed. It may be true that the construction of "the Palestinians" as the symbolic and universal victim thereby constructs "the Israelis" 
as symbolic of oppression everywhere. But this must itself already be a reversal. The Palestinians become universally symbolic because of their relationship with the Jews, who have a long history of being constructed as universally symbolic of all that is evil. Jewish crimes come before Palestinian victimhood in this symbolic register; the Palestinians simply get caught up in it and they get hurt by it.

The charges against Dreyfus were treated as though they were unfalsifiable. When some of the evidence was indeed found to have been falsified, it was proposed that there was other evidence which could not be made public, for the good of the nation. When evidence was produced against the real spy, it was said to have been manufactured by the Jewish conspiracy and even if it was true, it was held not to exonerate Dreyfus. And when one of the actual conspirators was imprisoned, the antisemites rallied round his innocent wife and his innocent child, they gave money, and they raged against the Jews who make the innocent suffer.

The Dreyfusards cared about republic; some of them cared about Dreyfus too. Antisemitism is about Jews but it is also always a form of appearance of antidemocratic politics, a symptom of profound corruption in any social space where it is tolerated. The two so often seem to be inseparable, the threat to actual Jews, and the corrosion of civic and democratic thought and practice.

If one wants to defend the democratic state, then it is clear that one has to be willing to recognize antisemitism and to fight against it. Socialists, republicans, democrats, and liberals may not be altogether pleased about this. There was some significant feeling on the French left at the time of Dreyfus that this was a fight between two privileged groups of army officers, the old aristocracy and the nouveau riche and cosmopolitan "finance capital" class, which had little to do with the genuinely oppressed.

There is sometimes a reluctance in opposing antisemitism because it looks like siding with the Jews; and there is always somebody who seems more deserving. Today one sees, for example, a suspicion that anybody who researches or teaches about the Holocaust is privileging that over other more deserving cases for some ulterior motive. One sees the claim that the Holocaust is only acknowledged as evil because the victims were "white," and that when white people murdered nonwhites around the world, nobody cared. Reasons to play down the importance of antisemitism, and to cast those who don't as vulgar and tribal, are abundant.

Today people are tempted by an analytical splitting of the world into the people of nowhere and the people of somewhere, the cosmopolitans and the "white working class." the liberal metropolitan elite and the "left behinds." Notwithstanding the fact that the working class is not white: it is diverse. But whiteness itself, in the context of the "white working class," has also come to be used as a sign of oppression. And then, in another reversal, racism and antisemitism comes to be seen as the cry of the oppressed rather than as oppressive power structures. A feeling lurks that Jews who demand that everybody opposes antisemitism are really demanding some kind of special privilege for themselves; and that the metropolitan liberals who insist on political correctness and antiracism are really creating rhetorical structures to keep the oppressed quiet and obedient.

The Holocaust is sometimes reconfigured as an attempt, in fact a conspiracy, to bolster Jewish power; or as a Eurocentric overconcern with atrocities by white people on white people. Here again, the Holocaust is no longer itself, but it becomes the Holocaust affair, a discourse manufactured, weaponized, exaggerated, controlled, by "the Jews." Holocaust Memorial Day becomes an opportunity for antisemitic discourse about Israel, the boxing in of actual Jews who are accused of supporting oppression, by the invocation of "the Jews" who are sanctified as absolute victims.

Today we live in an era when conspiracy fantasy is more and more attractive in mainstream political culture and in apparently diverse and distinct forms. Whether all our problems are 
imagined to be caused by the European Union or by the Zionists, by the globalists or by the finance capitalists, antidemocratic thinking is still attracted to antisemitism. And were not the persecutors of Alfred Dreyfus also great pioneers of "fake news"? And do not all conspiracy fantasists require ways of ignoring inconvenient facts and evidence which threaten to anchor them to material reality?

This piece by the much missed Robert Wistrich is worth reading. It is worth reading to understand what happened to Alfred Dreyfus; and to understand how the Dreyfus affair came to dominate France; and to understand French antisemitism; and to understand how it was one origin of twentieth-century totalitarianism; and to understand something about the present.

\section{Synopsis}

We are pleased to publish one of the last pieces that Robert Wistrich wrote, which is on Antisemitism in France at the time of Alfred Dreyfus. It is published with an introductory essay by David Hirsh which looks at how the issues Wistrich highlights around the Dreyfus affair may be read in the contemporary context of the re-emergence of antisemitism and populism into mainstream discourse.

\section{REFERENCES}

1 Robert Wistrich, From Ambivalence to Betrayal: The Left, the Jews, and Israel (Lincoln: University of Nebraska Press, 2012).

2 Hannah Arendt, The Origins of Totalitarianism (San Diego: Harvest, 1975), 120.

3 Telegraph Reporters, "Cambridge Union Audience Laughs at Anti-Semitic 'Joke' by Malaysian Prime Minister," The Daily Telegraph, June 18, 2019, https://www.telegraph.co.uk/news/2019/06/17/cambridge-union-audiencelaughs-anti-semitic-joke-malaysian/.

4 “Himmler's Posen Speech-'Extermination,"' Jewish Virtual Library, accessed September 17, 2019, https://www. jewishvirtuallibrary.org/himmler-s-posen-speech-quot-extermination-quot. 